\title{
Pengaruh Vitamin C terhadap Waktu Perdarahan Mencit yang Dipapar Asap Rokok
}

\author{
Alles Firmansyah ${ }^{1}$, Zelly Dia Rofinda ${ }^{2}$, Erkadius $^{3}$
}

\begin{abstract}
Abstrak
Asap rokok diketahui meningkatkan Reactive Oxygen Species (ROS). ROS dapat merusak pembuluh darah dan mengubah reaktivitas trombosit sehingga mengganggu sistem hemostasis. Vitamin $\mathrm{C}$ sebagai antioksidan esensial bagi tubuh terbukti dapat mengurangi kerusakan oksidatif akibat ROS. Tujuan penelitian ini adalah membuktikan potensi vitamin $\mathrm{C}$ dalam menghambat gangguan hemostasis melalui pengamatan waktu perdarahan mencit yang dipapar asap rokok. Penelitian Randomized Pre Test-Post Test Control Group Design ini dilakukan pada 21 ekor mencit jantan yang dibagi menjadi tiga kelompok. Pemberian perlakuan pada hari ke-1 hingga ke-14, yaitu P1 (kontrol negatif), P2 (paparan asap rokok 10 menit perhari), dan P3 (vitamin C 0,4 mg/gBB/hari + paparan asap rokok 10 menit perhari). Pengukuran waktu perdarahan metode tail bleeding pada hari ke-0 dan ke-15. Analisis data menggunakan uji $t$-paired, one-way Anova, dan post-hoc LSD. Hasil penelitian menunjukkan rerata waktu perdarahan P1 mengalami perubahan yang tidak bermakna dari 60,16 $\pm 3,27$ menjadi 57,61 \pm 4,88 detik. P2 mengalami perubahan yang bermakna dari 59,34 $\pm 6,93$ menjadi 38,85 $\pm 3,43$ detik. P3 mengalami perubahan yang bermakna dari 59,36 $\pm 3,07$ menjadi $51.85 \pm 3,45$ detik. Terdapat perbedaan rerata waktu perdarahan setelah perlakuan yang bermakna signifikan $(p=0,000)$ antara P2 dengan P3. Penelitian ini berhasil membuktikan potensi vitamin $C$ dalam mencegah pemendekan waktu perdarahan lebih lanjut sebagai indikator gangguan hemostasis akibat paparan asap rokok.
\end{abstract}

Kata kunci: vitamin C, asap rokok, ROS, waktu perdarahan

\section{Abstract}

Cigarette smoke is known to enhance Reactive Oxygen Species (ROS). ROS could damage vascular and alter platelet reactivity that makes abnormality of hemostatic system. Vitamin $C$ as an essential antioxidant for a body was proven could reduce oxidative stress due to ROS. The objective of this study was to prove that vitamin C can prevent decrease bleeding time of mice induced cigarette smoke as an indicator of hemostatic disorders inhibition effect. An experimental study with randomized pre test-post test control group design was conducted on 21 mice divided equally into three groups. Each group has different treatment for day 1 until day 14: Group I as control, group II was given cigarette smoke in 10 minutes per day, and group III was given vitamin C 0,4 mg/g BB/day + cigarette smoke in 10 minutes per day. The bleeding time was determined by a tail bleeding method on day 0 and day 15. T-paired, one-way Anova, and LSD post-hoc test were used to analyze the data. A P-value less than 0.05 considered significant.The result showed that group I had not a significant difference in mean of bleeding time from $60.16 \pm 3.27$ to $57.61 \pm 4.88$ seconds. Group II had a significant difference in mean of bleeding time from $59.34 \pm 6.93$ to $38.85 \pm 3.43$ seconds. Group III had a significant difference in mean of bleeding time from $59.36 \pm 3.07$ to $51.85 \pm 3.45$ seconds. Group II and group III had a significant difference in post-test mean of bleeding time $(p=0.000)$. This research proves the potency vitamin $C$ in preventing further decreased of bleeding time as an indicator of hemostatic disorders due to cigarette smoke exposure.

Keywords: vitamin C, cigarette smoke, ROS, bleeding time 
Affiliasi penulis: 1. Prodi Profesi Dokter FK Unand (Fakultas Kedokteran Universitas Andalas Padang); 2. Bagian Patologi Klinik FK unand; 3. Bagian Fisiologi FK Unand.

Korespondensi: Alles Firmansyah, Email: allesf.7@gmail.com Telp: 082285670760

\section{PENDAHULUAN}

Kebiasaan merokok sudah menjadi kebiasaan manusia sejak ratusan tahun yang lalu dan penggemarnya semakin lama semakin meningkat. Insiden perokok baru dewasa setiap tahunnya meningkat dari 600.000 orang pada tahun 2002 menjadi 1,1 juta orang pada tahun 2012. Insiden perokok baru berusia <18 tahun melebihi insiden perokok dewasa dan jumlah ini lebih meningkat pada negara-negara berkembang. ${ }^{1}$

Indonesia menempati peringkat ketiga dengan jumlah perokok terbesar di dunia. Pada tahun 1995, prevalensi perokok dewasa Indonesia adalah 26,9\%. Saat ini prevalensi perokok pada populasi berusia $>15$ tahun di Indonesia mencapai 36,3\%. Prevalensi perokok berdasarkan jenis kelamin terdiri atas $68,1 \%$ dari jumlah penduduk laki-laki Indonesia dan merupakan peringkat tertinggi di dunia, serta 4,3\% dari jumlah penduduk perempuan dewasa Indonesia.,

Merokok merupakan faktor risiko utama untuk timbulnya berbagai macam penyakit sehingga menyebabkan mortalitas yang tinggi bagi perokok maupun orang dengan pajanan asap rokok lingkungan. World Health Organization (WHO) melaporkan bahwa di dunia saat ini ada enam juta orang meninggal setiap tahunnya akibat rokok, lebih dari 600.000 orang akibat pajanan asap rokok lingkungan, dan 170.000 orang diantaranya adalah anak-anak. Jika tidak ada penanganan serius, maka pada tahun 2030 diperkirakan jumlah korban akan bertambah menjadi delapan juta orang dan sebagian besarnya terjadi di negara berkembang. ${ }^{3}$

Rokok memiliki banyak kandungan berbahaya bagi tubuh. Setiap satu batang rokok akan mengeluarkan lebih dari 5.000 bahan kimia yang dapat mengganggu sistem tubuh manusia, salah satunya adalah sistem hemostasis. ${ }^{4}$ Sistem hemostasis yang normal sangat penting bagi kehidupan dalam menjaga keseimbangan faktor trombogenik untuk mencegah hilangnya darah. Hemostasis yang berlebihan akan berisiko membentuk trombosis yang dapat mengancam jiwa seseorang. ${ }^{5,6}$

Riset membuktikan, baik perokok maupun orang dengan pajanan asap rokok lingkungan telah diketahui dapat meningkatkan sistem hemostasis secara berlebihan. Hasil pembakaran rokok akan mengakibatkan peningkatan reactive oxygen species (ROS) dan menurunkan antioksidan sistemik tubuh. Hal ini akan berdampak terhadap kerusakan pembuluh darah yang dapat meningkatkan vasokonstriksi dan mengubah reaktivitas dari trombosit sehingga meningkatkan agregasi trombosit secara berlebihan. Perubahan pada pembuluh darah dan trombosit akibat asap rokok dapat meningkatkan sistem hemostasis menjadi tidak terkontrol. ${ }^{7,8}$

Salah satu parameter yang digunakan untuk mengetahui gangguan pada proses hemostasis adalah waktu perdarahan. Parameter tersebut dapat menilai fungsi pembuluh darah dan trombosit sebagai bagian dari sistem hemostasis. ${ }^{9}$ Penelitian terdahulu yang menguji waktu perdarahan mencit dengan paparan asap rokok, didapatkan hasil bahwa asap rokok dapat memperpendek waktu perdarahan. ${ }^{8,10}$

Gangguan pada proses hemostasis akibat asap rokok sangat berpotensi dicegah oleh zat antioksidan. Vitamin $\mathrm{C}$ adalah antioksidan esensial bagi tubuh yang sudah dikenal efektif dalam menghambat peningkatan ROS dan mampu memperbaiki kerusakan pembuluh darah serta meningkatkan molekul vasodilatasi seperti nitric oxide (NO). ${ }^{11,12}$ Penelitian lain membuktikan vitamin C dapat menurunkan efek rokok terhadap peningkatan agregasi trombosit secara berlebihan pada mencit, dengan demikian vitamin $\mathrm{C}$ berpotensi dalam memperbaiki gangguan hemostasis akibat kerusakan pembuluh darah dan agregasi berlebihan dari trombosit. ${ }^{13}$

Berdasarkan pemaparan latar belakang permasalahan diatas, penulis merasakan pentingnya dilakukan penelitian mengenai potensi vitamin $\mathrm{C}$ dalam mencegah terjadinya gangguan hemostasis tubuh akibat hasil pembakaran rokok. Pada penelitian ini penulis akan melakukan pengamatan terhadap waktu perdarahan mencit yang dipapar asap rokok. 


\section{METODE}

Penelitian Randomized Pre Test-Post Test Control Group Design telah dilakukan pada bulan Desember 2015 di Animal House Fakultas Kedokteran Universitas Andalas. Subjek yang digunakan dalam penelitian ini adalah mencit putih jantan (Mus musculus) sebanyak 21 ekor yang diambil dengan teknik pengambilan sampel didasarkan pada kriteria inklusi dan eksklusi yang telah dibuat oleh peneliti.

Mencit terbagi dalam tiga kelompok untuk dilakukan perlakuan pada hari ke-1 hingga hari ke-14, yaitu kelompok kontrol negatif (P1), kelompok yang dipapar asap rokok selama sepuluh menit per hari (P2), dan kelompok yang diberi vitamin $C \quad 0,4 \mathrm{mg} / \mathrm{g}$ $\mathrm{BB} /$ hari per oral dua jam sebelum paparan asap rokok sepuluh menit setiap hari (P3). Pengukuran waktu perdarahan menggunakan metode tail bleeding pada hari ke-0 dan hari ke-15. ${ }^{14}$ Analisis data secara komputasi menggunakan uji t-paired, one-way Anova, dan post-hoc LSD.

\section{HASIL}

\section{Data penelitian}

Pengamatan waktu perdarahan antar mencit sebelum diberikan perlakuan dengan rerata antar kelompoknya diperlihatkan pada tabel berikut:

Tabel 1. Waktu perdarahan mencit sebelum perlakuan (detik)

\begin{tabular}{cccc}
\hline Mencit & P1-Pre & P2-Pre & P3-Pre \\
\hline $\mathbf{1}$ & 58,20 & 54,98 & 58,16 \\
$\mathbf{2}$ & 55,33 & 65,83 & 61,86 \\
$\mathbf{3}$ & 62,94 & 58,92 & 61,05 \\
$\mathbf{4}$ & 57,75 & 51,46 & 55,30 \\
$\mathbf{5}$ & 60,89 & 67,57 & 57,96 \\
$\mathbf{6}$ & 64,83 & 51,41 & 64,08 \\
$\mathbf{7}$ & 61,21 & 65,19 & 57,10 \\
\hline Rerata \pm SD & $60,16 \pm 3,27$ & $59,34 \pm 6,93$ & $59,36 \pm 3,07$ \\
\hline
\end{tabular}

Ket: $\quad P 1=$ kontrol negatif, $P 2=$ kelompok diberi asap rokok 10 menit, $P 3=$ kelompok diberi vitamin $C$ 0,4 mg/g BB dan asap rokok 10 menit.
Pada Tabel 1. terlihat perbedaan waktu perdarahan mencit antar kelompok. Seluruh sampel memiliki waktu perdarahan yang normal karena dalam rentang $62 \pm 18$ detik. ${ }^{15}$ Waktu perdarahan sebelum perlakuan terpanjang ditunjukkan oleh mencit ke-6 kelompok P2, sedangkan waktu perdarahan terpendek ditunjukkan oleh mencit ke-6 kelompok P2.

Pengamatan waktu perdarahan antar mencit setelah diberikan perlakuan dengan rerata antar kelompoknya diperlihatkan pada tabel berikut:

Tabel 2. Waktu perdarahan mencit setelah perlakuan (detik)

\begin{tabular}{cccc}
\hline Mencit & P1-Post & P2-Post & P3-Post \\
\hline $\mathbf{1}$ & 64,28 & 35,26 & 52,82 \\
$\mathbf{2}$ & 62,85 & 45,69 & 55,81 \\
$\mathbf{3}$ & 59,58 & 38,78 & 51,91 \\
$\mathbf{4}$ & 52,13 & 39,90 & 53,65 \\
$\mathbf{5}$ & 51,99 & 38,84 & 46,32 \\
$\mathbf{6}$ & 57,13 & 35,99 & 57,40 \\
$\mathbf{7}$ & 55,28 & 37,50 & 48,03 \\
\hline Rerata \pm SD & $57,61 \pm 4,88$ & $38,85 \pm 3,43$ & $51,85 \pm 3,45$ \\
\hline
\end{tabular}

Pada Tabel 2. terlihat perbedaan waktu perdarahan mencit antar kelompok. Seluruh sampel memiliki waktu perdarahan yang berbeda dengan waktu perdarahan sebelum perlakuan. Waktu perdarahan setelah perlakuan terpanjang ditunjukkan oleh mencit ke-1 kelompok P1, sedangkan waktu perdarahan terpendek ditunjukkan oleh mencit ke-1 kelompok P2.

\section{Analisis Data}

Data yang diperoleh kemudian diuji secara komputerisasi. Pengujian yang pertama dilakukan adalah uji normalitas data menggunakan Shapiro-Wilk Test, diperoleh bahwa data waktu perdarahan sebelum perlakuan berdistribusi normal $(p>0,05)$ yaitu dengan nilai 0,944 untuk kelompok $\mathrm{P} 1,0,198$ untuk kelompok P2, dan 0,802 untuk kelompok P3.

Pengujian selanjutnya adalah untuk mengetahui bermakna atau tidaknya perbedaan rerata waktu perdarahan sebelum dengan setelah perlakuan masing-masing kelompok mencit menggunakan uji $t$ paired disajikan dalam tabel berikut : 
Tabel 3. Analisis komparasi waktu perdarahan sebelum - sesudah perlakuan

\begin{tabular}{ccc}
\hline Kelompok & $\begin{array}{c}\text { Beda Rerata } \\
\text { Pre-Post (detik) }\end{array}$ & $\mathbf{P}$ \\
\hline P1 Pre-Post & 2,56 & 0,347 \\
P2 Pre-Post & 20,59 & 0,000 \\
P3 Pre-Post & 7,51 & 0,001 \\
\hline
\end{tabular}

Berdasarkan uji t-paired didapatkan bahwa terdapat pemendekan waktu perdarahan secara bermakna pada kelompok mencit yang terpapar asap rokok selama 10 menit per harinya baik dengan diberikan vitamin $C 0,4 \mathrm{mg} / \mathrm{g}$ BB dua jam sebelumnya (P3) maupun tidak diberikan vitamin $C(P 2)$ seperti pada gambar ini.

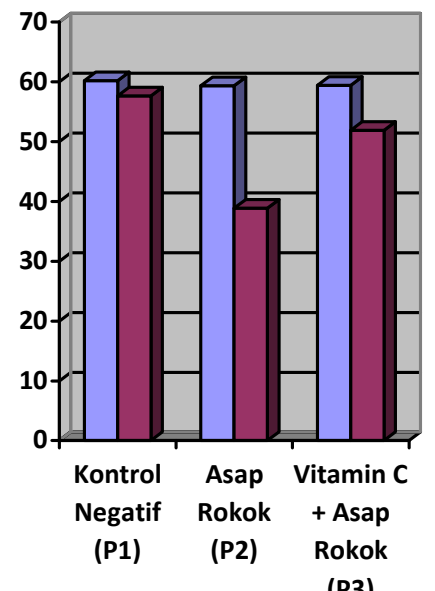

$\square$ Pre-test $\square$ Post-test

Gambar 1. Grafik pemendekan rerata waktu perdarahan setelah perlakuan

Analisis selanjutnya adalah uji komparabilitas untuk membandingkan rerata waktu perdarahan antar kelompok sebelum diberikan perlakuan. Hasil analisis kemaknaan menggunakan uji one way ANOVA dan diperoleh perbedaan yang tidak bermakna $(p>0,05)$ yaitu dengan nilai signifikansi 0,934 .

Pengaruh perlakuan dianalisis berdasarkan rerata waktu perdarahan antar kelompok setelah diberikan perlakuan. Hasil analisis kemaknaan menggunakan uji one way ANOVA menunjukkan bahwa nilai $p=0,000$. Hal ini berarti rerata waktu perdarahan pada ketiga kelompok setelah diberikan perlakuan berbeda secara bermakna $(p<0,05)$.
Uji untuk mengetahui kelompok-kelompok yang berbeda dilakukan uji menggunakan Least Significant Difference (LSD)-test. Hasil uji disajikan dalam tabel.

Tabel 4. Analisis komparasi waktu perdarahan setelah perlakuan antar kelompok

\begin{tabular}{ccc}
\hline Kelompok & $\begin{array}{c}\text { Beda rerata } \\
\text { Waktu } \\
\text { Perdarahan } \\
\text { (detik) }\end{array}$ & $\mathbf{P}$ \\
\hline P1 Post-P2 Post & 18,75 & 0,000 \\
P1 Post-P3 Post & 5,76 & 0,015 \\
P3 Post-P2 Post & 13,00 & 0,000 \\
\hline
\end{tabular}

Hasil uji lanjutan pada Tabel 4. menunjukkan bahwa rerata waktu perdarahan antar kelompok memiliki perbedaan yang bermakna secara signifikan $(p<0,05)$.

\section{PEMBAHASAN}

Paparan asap rokok sudah diketahui dapat mengganggu keseimbangan sistem hemostasis tubuh sehingga menjadi berlebihan melalui kerusakan pembuluh darah dan perubahan reaktivitas trombosit akibat peningkatan ROS. $^{8}$ Sebelum adanya perlakuan pemaparan asap rokok, seluruh mencit memiliki waktu perdarahan yang normal. Nilai normal waktu perdarahan mencit menggunakan metode tail bleeding sekitar 60 detik dengan rentang $62 \pm 18$ detik. $^{15}$

Perlakuan pada Tabel 3 memperlihatkan adanya pemendekan waktu perdarahan pada mencit yang dipapar asap rokok selama sepuluh menit per hari (P2 dan P3) dalam 14 hari. Dari hasil tersebut maka dapat diketahui bahwa hewan coba yang diuji telah mengalami pemendekan waktu perdarahan dibandingkan dengan sebelum perlakuan. Hal ini didukung oleh penelitian Hakam (2014), yaitu adanya pemendekan waktu perdarahan mencit yang dipapar asap rokok selama 10 menit per hari dalam 14 hari. ${ }^{10}$

Penelitian ini bertujuan untuk mengetahui pengaruh vitamin $\mathrm{C}$ terhadap waktu perdarahan mencit yang dipapar asap rokok sehingga dapat diketahui potensi yang dimiliki vitamin $\mathrm{C}$ dalam menghambat gangguan hemostasis akibat asap rokok. Vitamin C sebagai antioksidan esensial bagi tubuh terbukti dapat menetralisir ROS akibat paparan asap 
rokok. ${ }^{13,16}$ Hasil penelitian ini menunjukkan pengaruh vitamin C dalam menekan reaksi pemendekan waktu perdarahan sebagai indikator gangguan sistem hemostasis karena pada tabel 2. terlihat rerata waktu perdarahan kelompok P3 lebih panjang dibandingkan dengan kelompok P2.

Analisis pengaruh vitamin $\mathrm{C}$ pada mencit yang dipapar asap rokok (P3) pada tabel 4. memiliki perbedaan rerata waktu perdarahan yang bermakna secara signifikan $(p=0,000)$ dibandingkan dengan kelompok mencit yang hanya dipapar asap rokok saja (P2). Dalam penelitian ini, vitamin C dosis $0,4 \mathrm{mg} / \mathrm{g}$ $\mathrm{BB} /$ hari bagi mencit sudah mampu menetralisir ROS akibat paparan asap rokok. Hasil penelitian ini berbeda dengan kesimpulan yang didapatkan oleh penelitian Ishlahiyah (2006) dimana pemberian vitamin $\mathrm{C}$ dosis $0,4 \mathrm{mg} / \mathrm{g} \mathrm{BB} /$ hari untuk mencit belum mampu menetralisir ROS akibat paparan asap rokok. ${ }^{17}$

Perbedaan kesimpulan dapat terjadi diduga karena ROS akibat paparan asap rokok yang diberikan terlalu banyak sehingga tidak dapat dinetralisir seluruhnya oleh vitamin C. Kemungkinan lain ialah jarak waktu yang kurang lama diberikan terhadap mencit antara pemberian vitamin C per oral dengan paparan asap rokok karena dibutuhkan waktu yang cukup dalam penyerapan vitamin C agar terserap optimal sehingga mampu menetralisir ROS akibat asap rokok.

Penelitian lain sejalan dengan temuan penelitian ini dilakukan oleh Hafiz (2010) dan Claudia et al (2013) yang menghasilkan kesimpulan yakni terdapat perbedaan yang bermakna signifikan antara kelompok mencit yang diberikan vitamin C dan paparan asap rokok dengan kelompok yang hanya diberikan paparan asap rokok tanpa vitamin C. ${ }^{18,19}$

Pada kelompok mencit kontrol negatif (P1) terdapat perbedaan rerata waktu perdarahan yang signifikan dibandingkan dengan kelompok mencit P2 dan P3 setelah perlakuan yang terdapat pada tabel 3. $(p<0,05)$. Kesimpulan ini juga sejalan dengan laporan Muliartha (2009) yang menjelaskan adanya perbedaan yang bermakna antara kelompok mencit kontrol negatif dengan kelompok mencit yang diberikan vitamin $\mathrm{C}$ dan dipapar asap rokok. Walaupun terdapat perbedaan yang bermakna antara kelompok $\mathrm{P} 1$ dengan $\mathrm{P} 3$, perbedaan tersebut tidak menyebabkan mencit kelompok P3 mengalami pemendekan rerata waktu perdarahan dari rentang normal. Berbeda dengan pemendekan rerata waktu perdarahan pada kelompok $\mathrm{P} 2$ yang rerata waktu perdarahannya sudah tidak dalam rentang normal. ${ }^{20}$

Hasil penelitian ini menunjukkan bahwa vitamin C telah dibuktikan mampu menjaga waktu perdarahan mencit tetap normal dan berperan sebagai faktor preventif dalam menetralisir stres oksidatif akibat asap rokok terhadap sistem hemostasis. Berdasarkan hasil penelitian tersebut maka dapat dinyatakan bahwa pemberian vitamin $\mathrm{C}$ memiliki pengaruh yang bermakna secara signifikan terhadap waktu perdarahan mencit yang dipapar asap rokok.

Penelitian ini memiliki keterbatasan yaitu tidak dapat menentukan dosis optimal vitamin $\mathrm{C}$ dalam menjaga keseimbangan sistem hemostasis karena menggunakan satu varian dosis saja. Selain itu dalam penelitian ini belum mampu melihat gangguan hemostasis secara holistik karena hanya dilakukan pemeriksaan terhadap waktu perdarahan.

\section{SIMPULAN}

Rerata waktu perdarahan pada kelompok mencit yang dipapar asap rokok dan tidak diberi vitamin C lebih pendek daripada kelompok mencit kontrol negatif.

Rerata waktu perdarahan pada kelompok mencit yang dipapar asap rokok dan diberi vitamin $\mathrm{C}$ lebih panjang daripada kelompok mencit yang dipapar asap rokok dan tidak diberi vitamin C.

Terdapat perbedaan rerata waktu perdarahan yang bermakna signifikan antara kelompok mencit yang dipapar asap rokok dan diberi vitamin $C$ dengan kelompok mencit yang dipapar asap rokok dan tidak diberi vitamin $\mathrm{C}$.

\section{UCAPAN TERIMA KASIH}

Terima kasih kepada semua atas bimbingan, bantuan, dan motivasi dalam penelitian ini. Kepada Yandrizmal, S.Pt atas arahan teknis penelitian serta pihak lainnya yang telah memberikan kontribusi dalam pelaksanaan penelitian ini. 


\section{DAFTAR PUSTAKA}

1. Mozzafarian D, Benjamin EJ, Go AS, Arnet DK, Blaha MJ, Cushman M, et al. Heart disease and stroke statistic-2015 update: a report from American Heart Association. Circulation. 2015;131:e299-e322.

2. Badan Penelitian dan Pengembangan Kesehatan. Riset kesehatan dasar (Riskesdas) 2013. Jakarta: Kementerian Kesehatan Republik Indonesia; 2013.

3. World Health Organization (WHO). Global status report on noncommunicable disease 2014. Geneva: World Health Organization; 2014.

4. Talhout R, Schulz T, Florek E, van Benthem J, Wester P, Opperhuizen A. Hazardous compounds in tobacco smoke. Int J Environ Res Publ Health. 2011;65(1):24-9.

5. Lijfering WM, Flinterman LE, Vandenbroucke JP, Rosendaal FR, Cannegieter SC. Relationship between venous and arterial thrombosis: a review of the literature from a causal perspective. Semin Thromb Hemost. 2011;37(8):885-96.

6. Hall JE. Textbook of medical physiology. $13^{\text {th }}$ edition. Philadelphia: Elsevier Saunders; 2016.

7. Middlekauff HR, Park J, Moheimani RS. Adverse effect of cigarette and noncigarette smoke exposure on the autonomic nervous system. J Am Coll Cardiol. 2014;64(16):1740-50.

8. Karim ZA, Alshbool FZ, Vemana HP, Adhami N, Dhall S, Espinosa EV. Third-hand smoke: impact on hemostasis and thrombogenesis. J Cardiovasc Pharmacol. 2015;66(2):177-82.

9. Tantanate $C$. The Bleeding time: review of basic principle, clinical applications, and laboratory pitfalls. Siriraj Med J. 2013;65(1):24-9.

10. Hakam IU. Perbedaan kecepatan waktu perdarahan (bleeding time) pada mencit yang dipapar asap rokok dengan mencit yang tidak dipapar asap rokok. UNEJ Repository. 2014. hlm. 6-7.

11. Ashor AW, Siervo M, Lara J, Oggioni C, Mathers JC. Antioxidant vitamin supplementation reduces arterial stiffness in adults: a systematic review and meta-analysis of randomized controlled trials. J Nutr. 2014;144(10):1594-602.
12. Maldonado AS, Hidalgo M, Artega $P$, Teresa SP, Nova E. Effect of regular consumption of vitamin Crich or polyphenol-rich apple juice on cardiometabolic markers in healthy adults a randomized crossover trial. Eur $\mathrm{J}$ Nutr. 2014;53(8):1645-57.

13. Fahim MA, Nemmar A, Singh $S$, Hasan MY. Antioxidant alleviate nicotine-induced platelet aggregation in cerebral arteriol of mice in vivo. Physiol Res. 2011;60(4):695-700.

14. Astuti KW. Kombinasi asetosal dan ekstrak buah mengkudu (Morinda citrifolia I.) dapat memperpanjang waktu perdarahan dan koagulasi pada mencit (tesis). Denpasar, Indonesia: Fakultas Kedokteran Universitas Udayana. 2010. hlm. 5154.

15. Greene TK, Schiviz A, Hoellrigl W, Poncz M, Muchitsch EM. Towards a standardization of the murine tail bleeding model. J Thromb Haemost. 2010;8:2820-22.

16. Das A, Dey N, Ghosh A, Das S, Chattopadhway DJ, Chatterjee IB. Molecular and cellular mechanism of cigarette smoke induced myocardial injury: prevention by vitamin C. PLoS ONE. 2012;7(9):e44151.

17. Ishlahiyah C. Pengaruh pemberian vitamin C terhadap jumlah spermatozoa mencit jantan strain balb/c yang diberi paparan asap rokok. Diponegoro University Repository. 2006. hlm. 7-10.

18. Hafiz A. Pengaruh pemberian vitamin $C$ terhadap motilitas spermatozoa mencit jantan strain balb/c yang diberi paparan asap rokok. Diponegoro University Repository. 2010. hlm. 6-9.

19. Claudia V, Queljoe ED, Tendean L. Perbedaan kualitas spermatozoa mencit jantan (Mus musculus) yang diberikan vitamin $\mathrm{C}$ setelah pemaparan asap rokok. Jurnal e-Biomedik. 2013;1(1):629-34.

20. Muliartha IKG, Sriwahyuni E, Yuliawati. Pemberian kombinasi vitamin $\mathrm{C}$ dan $\mathrm{E}$ peroral memperbaiki kerusakan hepar akibat paparan asap rokok kretek sub kronik. Jurnal Kedokteran Brawijaya. 2009;24(1):23-7. 